\title{
Sumber-Sumber Efikasi Diri Karier Remaja
}

\section{Sources of Career Self-Efficacy on Adolescents}

\author{
Rini Astuti ${ }^{1} \&$ William Gunawan ${ }^{2}$ \\ Fakultas Psikologi Universitas Kristen Krida Wacana \\ Jl. Tanjung Duren Raya No. 4 Jakarta 11470 \\ email : astute.rini.999@gmail.com; william.gunawan@ukrida.ac.id
}

\begin{abstract}
KATA KUNCI
Efikasi diri karier, Remaja

KEYWORDS

Career Self-Efficacy, Adolescents
\end{abstract}

ABSTRAK

ABSTRACT

Efikasi diri merupakan salah satu aspek yang mempengaruhi perkembangan karier remaja. Efikasi diri yang berhubungan dengan karier disebut efikasi diri karier, keyakinan diri seseorang tentang kemampuannya untuk melakukan aktivitas karier yang berkaitan dengan pengembangan karier, pilihan karier dan penyesuaian karier. Efikasi diri karier ini terbentuk melalui sumber-sumber efikasi diri karier yang terdiri dari mastery experience, vicarious learning, verbal persuasion, psychological states. Penelitian ini bertujuan untuk melihat gambaran sumber-sumber efikasi diri karier pada remaja di Jakarta Barat. Metode penelitian yang digunakan adalah kuantitatif deskriptif dengan teknik pengambilan sampel purposive sampling. Penelitian ini menggunakan 445 subyek yang berasal dari 3 SMA, yaitu SMA Negri 2, SMA IPEKA Tomang dan SMA Al-Huda di Jakarta Barat. Berdasarkan hasil analisa deskriptif, diketahui gambaran sumber-sumber efikasi diri karier remaja SMA di Jakarta Barat tergolong tinggi. Jika dilihat berdasarkan dimensi sumber-sumber efikasi diri karier maka sumber-sumber yang membentuk efikasi diri karier remaja SMA di Jakarta Barat adalah mastery experience, vicarious learning, verbal persuasion, dan positive emotional arousal.

One aspect that influence adolescence's career development is selfefficacy. Career Self-efficacy defined as an individual belief regarding one's ability to involve in career activities that related with career development, career choice and career adaptability. Career self-efficacy influenced by sources of career self-efficacy, namely mastery experience, vicarious learning, verbal persuasion, psychological states. This research was aimed to explore the sources of career self-efficacy among adolescence in West Jakarta. Quantitative descriptive which purposive sampling techniques was used in this research. A sample of 445 adolescent from 3 high school student was used. The result showed that the sources of career self-eficacy among adolescent in West Jakarta was high. The dimensions that form sources of career self-efficacy were mastery experience, vicarious learning, verbal persuasion, dan positive emotional arousal. 


\section{PENDAHULUAN}

Efikasi diri adalah keyakinan seseorang terhadap kemampuannya untuk menyelesaikan suatu tugas. Menurut Bandura (1997), efikasi diri merupakan keyakinan seseorang akan kemampuan untuk melakukan suatu hal yang diperlukan untuk mencapai suatu keberhasilan. Efikasi diri pertama kali diterapkan dalam perilaku yang berhubungan dengan karier oleh Hackett dan Betz (Bozgeyikli, Susran, Erkan, \& Habib 2009) dan selanjutnya diteliti oleh peneliti lain dalam perkembangan karier (Betz, Klein, \& Taylor (2012); Gunawan (2013), Lestari (2012); Lin (2008); Rachmawati (2012). Efikasi diri karier dapat didefinisikan sebagai penilaian seseorang tentang kemampuan mereka untuk melakukan perilaku karier dalam kaitannya dengan pengembangan karier, pilihan, dan penyesuaian (Anderson \& Betz, 2001; Betz, Klein, \&Taylor (2012); Niles \& Sowa, 1992). Jadi, dapat dikatakan bahwa efikasi diri karier adalah keyakinan seseorang terhadap kemampuannya untuk membuat keputusan dalam hal karier.

Betz (1992) mengatakan seseorang dengan efikasi diri karier yang rendah akan cenderung menunda-nunda untuk mengambil keputusan karier. Sandler (Ferguson, 2007) menyimpulkan bahwa ketika seorang siswa mampu membuat keputusan karier dan memiliki tujuan, disertai dengan efikasi diri dalam mencapai tujuan ini, mereka akan memiliki kekuatan untuk menyelesaikan tujuan tersebut.

Bandura (Bacanli, 2006) mengatakan bahwa efikasi diri dikembangkan dan ditingkatkan melalui empat proses utama dan sumber informasi. Empat proses dan sumber informasi tersebut adalah, 1) pengalaman pencapaian di masa lalu dan pengalaman keberhasilan (mastery experience), 2) pengalaman belajar yang beragam melalui proses observasi terhadap tokoh teladan dan proses peniruan terhadap tokoh tersebut (vicarious learning), 3) persuasi verbal seperti pengaruh lingkungan sosial dan dorongan dari orang lain (verbal persuasion), 4) kondisi psikologis dan emosional (psychological states). Sumber-sumber efikasi diri ini sangat penting untuk memahami perkembangan efikasi diri.

Penelitian Nasta (2007) mengatakan bahwa ada hubungan yang signifikan antara sumber-sumber efikasi diri karier dengan efikasi diri karier. Sumber-sumber efikasi diri ini memiliki pengaruh yang besar dalam pembentukan efikasi diri karier. Kurangnya prestasi masa lalu, pengalaman belajar, tidak adanya persuasi verbal atau dorongan dari orang lain dapat mempengaruhi efikasi diri karier menjadi negatif (Betz \& Hackett, 1986). Seseorang yang memiliki keempat sumber efikasi diri tersebut cenderung memiliki efikasi diri karier yang tinggi, dan keyakinan akan kemampuannya tersebut membentuk seseorang sehingga mampu mengambil keuputusan karier untuk dirinya. Jadi, pengalaman negatif dengan empat sumber efikasi diri tersebut, menyebabkan rendahnya efikasi diri karier seseorang.

Berdasarkan penelitian yang dilakukan oleh Nasta (2007), efikasi diri karier memiliki korelasi yang signifikan dengan vicarious learning $(\mathrm{r}=.32, \mathrm{p}<.05)$, verbal persuasion $(\mathrm{r}=.48, \mathrm{p}<.05)$, emotional arousal positive $(\mathrm{r}=.44, \mathrm{p}<.05)$, mastery experience $(\mathrm{r}=.59, \mathrm{p}<.05)$, dan korelasi negatif terhadap emotional arousal negative $(\mathrm{r}=-.45, \mathrm{p}<.05)$. Penelitian ini menunjukkan bahwa prestasi kinerja memiliki korelasi tertinggi dengan efikasi diri karier.

Berbagai penelitian mengenai efikasi diri banyak ditemukan di Indonesia, akan tetapi penelitian-penelitian tersebut hanya melihat pengaruh maupun hubungan efikasi diri tersebut dengan variabelvariabel lainnya. Belum banyak penelitian yang melihat peran sumber-sumber efikasi diri ini terhadap pembentukan efikasi diri dalam diri seseorang. Dengan adanya penelitian ini, maka dapat diketahui peran masing-masing sumber efikasi diri dalam pembentukan efikasi diri pada remaja. Setelah diketahui peran masing-masing 
sumber, maka dapat dilakukan intervensi untuk meningkatkan efikasi diri pada remaja tersebut.

Penelitian ini menggunakan subyek yang berusia 17-18 tahun karena menurut tahapan perkembangan karier, usia tersebut berada pada tahap transisi (Brown \& Lent, 2014). Remaja pada usia tersebut seharusnya mampu memikirkan atau merencanakan karier mereka berdasarkan minat, kemampuan dan nilai-nilai yang ingin diperjuangkan. Berdasarkan latar belakang diatas, maka penelitian ini ingin melihat "Bagaimana gambaran sumbersumber efikasi diri karier pada remaja?". Penelitian ini bertujuan untuk melihat gambaran sumber-sumber efikasi diri karier pada remaja.

\section{Sumber-sumber Efikasi Diri Karier}

Sumber-sumber efikasi diri adalah stimulasi atau kejadian yang dapat memberikan inspirasi atau pembangkit positif (positive arousal) untuk berusaha menyelesaikan tugas atau masalah yang dihadapi (Lazarus et.al., 1980). Menurut Bandura (Ariani, 2011), efikasi diri dapat terbentuk dan berkembang melalui empat proses yaitu kognitif, motivasional, afektif dan seleksi. Efikasi diri berkembang melalui empat sumber informasi utama. Keempat sumber-sumber efikasi diri tersebut dapat berasal dari: (a) pengalaman individu (mastery experience), (b) pengalaman orang lain (vicarious learning), (c) persuasi Verbal (verbal persuasion), (d) kondisi psikologis dan emosional (psychological states) (Bacanli, 2006).Sumber-sumber efikasi diri dapat dikatakan juga sebagai sarana untuk membentuk efikasi diri seseorang.

Mastery experience dapat juga disebut pengalaman langsung dan pencapaian prestasi di masa lalu. Seseorang yang memiliki pengalaman sukses cenderung menginginkan hasil yang cepat dan lebih mudah jatuh karena kegagalan. Beberapa kesulitan dan kegagalan diperlukan untuk membentuk individu yang kuat dan mengajarkan manusia bahwa kesuksesan membutuhkan suatu usaha, seseorang yang memiliki keyakinan akan sukses mendorongnya untuk bangkit dan berusaha untuk mewujudkan kesuksesan tersebut (Muretta, 2004). Bandura (1986) menekankan bahwa pengalaman ini adalah sumber informasi efikasi diri yang paling kuat dan berpengaruh.

Vicarious learning, pengalaman orang lain adalah pengalaman pengganti yang disediakan guna untuk model sosial melalui pengamatan terhadap orang lain. Mengamati perilaku dan pengalaman orang lain sebagai proses belajar individu (Wulandari, n.d.). Dampak modeling dalam efikasi diri sangat dipengaruhi oleh kemiripin antara individu dengan model. Sumber berikutnya adalah verbal persuasion, sumber informasi ini dapat mempengaruhi bagaimana seseorang bertindak atau berperilaku. Dengan persuasi verbal, individu mendapat sugesti bahwa ia mampu mengatasi masalahmasalah yang akan dihadapi. Persuasi verbal digunakan untuk meningkatkan keyakinan seseorang mengenai hal-hal yang dimilikinya untuk berusaha lebih gigih dalam mencapai tujuan dan keberhasilan atau kesuksesan (Ariani, 2011).

Sumber efikasi diri yang terakhir adalah psychological states, situasi yang menekan kondisi emosional dapat mempengaruhi efikasi diri (Muretta, 2004). Kondisi emosional juga mempengaruhi individu dalam mengambil keputusan kariernya. Berdasarkan penjelasan diatas dapat disimpulkan bahwa efikasi diri dapat tumbuh melalui pengalaman dari hasil yang telah dicapai oleh individu tersebut, pengalaman orang lain, persuasi verbal, serta keadaan psikologis dan emosional.

Interaksi antara keempat sumber efikasi ini lebih lanjut dijelaskan oleh Bandura (1997) dengan berbagai kondisi. Interaksi pertama, bersifat additive, semakin banyak sumber-sumber efikasi diri yang dimiliki seseorang, semakin besar pula kemungkinan memiliki efikasi 
diri yang tinggi. Kedua, bersifat relative, yaitu menyatakan bahwa salah satu sumber-sumber efikasi diri lebih kuat daripada sumber yang lain. Ketiga, bersifat multicative, yaitu dua sumber yang menunjukkan sebuah efek interaktif. Keempat, bersifat configurative, yaitu kekuatan dari satu sumber efikasi diri tergantung dari adanya sumber-sumber lainnya.

Berdasarkan uraian-uraian diatas, peneliti menyimpulkan bahwa sumbersumber efikasi diri adalah kejadian atau situasi yang membangkitkan keyakinan seseorang akan kemampuannya dalam menyelesaikan suatu tugas.

\section{Perkembangan Karier Remaja}

Ginzberg, Ginzburg, Axelrad, dan Herma (1951) merupakan kelompok yang menjelaskan mengenai perkembangan karier. Kelompok ini memandang perkembangan karier sebagai proses pemilihan karier yang dapat dibagi menjadi tiga tahap pokok yaitu: tahap fantasi, tahap tentative dan tahap realistis. Tahap fantasi dari usia lahir sampai 11 tahun, anak hanya bermain-main saja dan belum memiliki kesadaran yang cukup dalam hal pemilihan karier. Anak memiliki cita-cita tetapi belum dapat membedakan antara keinginan sendiri atau keinginan orang lain (Winkel, 1991).

Tahap tentatif, usia 12 sampai dengan 18 tahun. Pada tahap ini terdapat empat periode, yaitu: tahap minat, kemampuan, nilai dan transisi. Tahap minat (11-12 tahun), anak mulai mengambil sikap terhadap apa yang disukai dan tidak disukainya. Tahap kemampuan (13-14 tahun), anak menyadari kemampuannya dan melihat kapasitasnya dalam menentukan tujuan. Tahap nilai-nilai (1516 tahun), anak sudah bisa membedakan mana kegiatan atau pekerjaan yang dihargai oleh masyarakat, dan mana yang kurang dihargai. Tahap transisi (17-18 tahun), anak sudah mampu memikirkan atau merencanakan karier mereka berdasarkan minat, kemampuan dan nilai- nilai yang ingin diperjuangkan. Remaja sudah dapat membuat pilihan karier, bertanggung jawab dan melakukan perubahan dari dunia sekolah ke dunia kerja (Winkel, 1991).

Tahap terakhir adalah tahap realistik, dari usia 19-25 tahun. Tahap realistik dibagi menjadi tiga sub tahap. Tahap pertama dimulai dengan eksplorasi dan mempertimbangkan beberapa alternatif jabatan.Kemudian masuk pada tahap kristalisasi, di mana remaja mulai merasa lebih mantap jika memiliki sebuah jabatan tertentu. Tahap terakhir, tahap penentuan, remaja mulai membuat keputusan tentang jabatan tertentu (Winkel, 1991).

\section{METODE PENELITIAN}

Penelitian ini menggunakan pendekatan kuantitatif deskriptif. Menurut Azwar (2013), penelitian deskriptif adalah suatu penelitian yang bertujuan untuk menggambarkan secara sistematik, akurat, dan karakteristik mengenai populasi atau mengenai bidang tertentu. Penelitian ini menggunakan subyek remaja SMA berusia 17-18 tahun yang berada di Wilayah Jakarta Barat. Menurut Brown dan Lent (2014) pada rentang usia tersebut, mereka berada pada tahap transisi, anak sudah mampu memikirkan atau merencanakan karier mereka berdasarkan minat, kemampuan dan nilai-nilai yang ingin diperjuangkan. Subyek penelitian ini berjumlah 445 siswa SMA yang berada di wilayah Jakarta Barat.

Pengambilan sampel dilakukan dengan menggunakan teknik purposive sampling, pengambilan sampel berdasarkan karakteristik dan ciri-ciri tertentu. Metode ini mengacu pada penentuan kriteria subyek dan obyek yang menjadi tujuan dalam penelitian (Azwar, 2013). Penentuan kriteria dalam penelitian ini berdasarkan tujuan penelitian. yaitu remaja berusia 1718 tahun yang berada di Wilayah Jakarta Barat. Pengambilan sampel dilakukan di tiga kecamatan yang terdapat di wilayah Jakarta Barat. Ketiga kecamatan tersebut adalah Kebon Jeruk, Cengkareng, dan 
Taman Sari. Masing-masing kecamatan diwakilkan oleh satu sekolah. SMA 2 yang terdapat di kecamatan Taman Sari dengan jumlah 217 subyek. SMA IPEKA Tomang mewakili Kebon Jeruk dengan jumlah 99 subyek. SMA Al-Huda mewakili kecamatan Cengkareng dengan jumlah 129 subyek.

Definisi operasional dari Sumbersumber efikasi diri karier adalah skor total dan skor masing-masing dimensi dari alat ukur Career Self-Efficacy Sources Scale (Skala Sumber-Sumber Efikasi Diri Karier). Alat ukur Career Self-Efficacy Sources Scale ini terdiri dari lima dimensi, yaitu (a) pengalaman individu (mastery experience), (b) pengalaman orang lain (vicarious learning), (c) persuasi verbal (verbal persuasion), (d) dorongan emosional positif, dan (e) dorongan emosional negatif.
Uji validitas dan reliabilitas pada penelitian ini menggunakan 30 subyek yang berasal dari SMK PGRI 35, Jakarta Barat. Uji validitas menggunakan validitas konstruk, validitas yang menunjukkan sejauhmana tes tersebut mengungkapkan konstruk teoritis yang hendak diukur. Koefisien validitas yang kurang dari 0,3, dianggap tidak memuaskan atau tidak valid. Uji reliabilitas menggunakan pendekatan reliabilitas isi, dengan cara pengukuran konsistensi internal dengan menggunakan rumus Cronbach's Alpha. Koefisien reliabilitas berkisar mulai dari 0,0 sampai 1,0. Jadi, semakin mendekati angka 1,0 maka menunjukkan bahwa alat tes tersebut semakin reliabel (Azwar, 2012). Blue print alat ukur Career SelfEfficacy Sources Scaleyang telah valid dan reliabel dapat dilihat pada tabel 1 .

Tabel 1. Blueprint Skala Sumber-Sumber Efikasi Diri Karier

\begin{tabular}{|c|c|c|c|}
\hline Dimensi & Contoh Item & No. Item & $\begin{array}{c}\text { Jumlah } \\
\text { Item }\end{array}$ \\
\hline Mastery & Berdasarkan prestasi saya di kampus, saya percaya saya & $2,6,16$ & \\
\hline Experience & akan berhasil dalam mencari pekerjaan. & 20 & 4 \\
\hline Vicarious & Saya melihat mahasiswa seperti saya mendapat pekerjaan & $1,8,11$ & \\
\hline Experience & yang baik setelah lulus kuliah. & 14 & 4 \\
\hline Verbal & Orang-orang mengatakan bahwa saya akan mendapat & $4,9,12$ & \\
\hline Persuasion & pekerjaan dengan mudah. & 18 & 4 \\
\hline $\begin{array}{l}\text { Positive } \\
\text { emotional } \\
\text { Arousal } \\
\text { Negative }\end{array}$ & $\begin{array}{l}\text { Saya merasa sangat senang ketika saya berusaha } \\
\text { melakukan sesuatu untuk mencari pekerjaan. }\end{array}$ & $\begin{array}{c}3^{*}, 7^{*}, 13 \\
19\end{array}$ & 4 \\
\hline $\begin{array}{l}\text { Emotional } \\
\text { Arousal }\end{array}$ & $\begin{array}{l}\text { Saya merasa was-was setiap kali saya memikirkan cara } \\
\text { mencari kerja. }\end{array}$ & $\begin{array}{l}5^{*}, 10^{*} \\
15^{*}, 17\end{array}$ & 4 \\
\hline Total Item & & 20 & $1-20$ \\
\hline
\end{tabular}

(Sumber: Skala Sumber-Sumber Efikasi Diri Karier dikembangkan oleh Nasta, 2007)

(*) Aitem yang gugur

\begin{abstract}
ANALISIS \& HASIL
Sebelum melakukan analisa data, peneliti juga melakukan uji normalitas dengan menggunakan Kolmogrov-Smirnov Goodness of Fit. Berdasarkan hasil uji normalitas, diketahui skala sumber-sumber efikasi diri karier menunjukkan nilai Kolmogorov-Smirnov sebesar $\quad 0,143$
\end{abstract}

( $p>0,05)$. Dapat dikatakan bahwa skala sumber-sumber efikasi diri karier memiliki sebaran data normal sehingga analisa hasil penelitian dapat dilakukan dengan menggunakan uji statistik parametrik. 
Tabel 2. Hasil Uji Beda Sumber Efikasi Diri Karier berdasarkan Data Demografi

\begin{tabular}{cl}
\hline \multicolumn{2}{c}{ Data Demografi Partisipan Penelitian } \\
\hline \multirow{3}{*}{ Sekolah } & SMA 2 \\
& SMA IPEKA Tomang \\
& SMA Al-Huda \\
Jenis Kelamin & Perempuan \\
& Laki-laki \\
Usia & 17 Tahun \\
& 18 Tahun \\
Kelas & IPA \\
& IPS
\end{tabular}

Hasil perhitungan yang telah dilakukan menunjukkan bahwa sumbersumber efikasi diri karier remaja usia 1718 tahun di Jakarta Barat tergolong dalam kategori tinggi, dengan nilai rata-rata sebesar 49,31. Ketiga sekolah memiliki sumber-sumber efikasi diri karier yang tergolong tinggi. Dengan SMA 2 memiliki nilai rata-rata paling besar dibandingkan dua sekolah lainnya. Dimensi yang berkontribusi tinggi dalam pembentukan efikasi diri karier remaja adalah Vicarious Learning, Mastery Experience, Positive Emotional Arousal, dan Verbal Persuasion.

Berdasarkan uji beda dengan One Way Anova, diketahui ketiga sekolah SMA tersebut memiliki perbedaan yang signifikan. Selain itu berdasarkan jenis kelamin juga terdapat perbedaan yang signifikan antara sumber-sumber efikasi diri karier pada perempuan dan laki-laki. Berdasarkan usia, diketahui tidak terdapat perbedaan yang signifikan antara keduanya. Tidak terdapat perbedaan juga antara kelas jurusan IPA dan IPS.

Sumber-sumber efikasi diri adalah stimulasi atau kejadian yang dapat memberikan inspirasi atau pembangkit positif (positive arousal) untuk berusaha menyelesaikan tugas atau masalah yang dihadapi (Bandura, dalam Lazarus et.al., 1980). Menurut Bandura (Musyafik, 2005), keyakinan diri atau efikasi diri seseorang dapat ditingkatkan melalui sumber-sumber efikasi diri. Jika seseorang memiliki sumber-sumber efikasi diri tinggi maka

$\begin{array}{ccc}\text { Mean } & \mathrm{F} & \mathrm{p} \\ 50,33 & 3,956 & 0,02 \\ 48,51 & & \\ 48,21 & & \\ 50,23 & 7,625 & 0,006 \\ 48,26 & & \\ 49,45 & 1,415 & 0,235 \\ 48,02 & & \\ 49,6 & 0,638 & 0,425 \\ 49,03 & & \end{array}$

orang tersebut juga pasti memiliki keyakinan diri atau efikasi diri yang tinggi juga. Yulia (2010) mengatakan bahwa seseorang yang memiliki efikasi diri rendah akan cenderung untuk menundanunda dalam menyelesaikan suatu tugas atau pekerjaan. Hasil penelitian menunjukkan bahwa sumber-sumber efikasi diri karier remaja pada usia 17-18 tahun tergolong tinggi. Sumber-sumber efikasi diri karier remaja yang tinggi memiliki arti bahwa siswa-siswi pada penelitian ini memiliki efikasi diri karier yang tinggi juga, sehingga mereka merasa yakin dengan kemampuannya untuk berhasil. Karakteristik individu yang memiliki efikasi diri tinggi adalah ketika individu tersebut merasa yakin bahwa mereka mampu menangani sesecara efektif peristiwa dan situasi yang mereka hadapi, tekun dalam menyelesaikan tugastugas, percaya pada kemampuan diri, menetapkan sendiri tujuan yang akan mereka tuju dan meningkatkan komitmen yang kuat terhadap dirinya, menanamkan usaha yang kuat dalam hal yang dilakukannya dan meningkatkan usaha saat menghadapi kegagalan, berfokus pada tugas, dan menghadapi stressor atau ancaman dengan keyakinan bahwa mereka mampu mengontrolnya (Bandura, 1997).

Hasil perhitungan per dimensi menunjukkan 4 (empat) dimensi yang memiliki kontribusi tertinggi dalam sumber-sumber efikasi diri karier remaja usia 17-18 tahun di Jakarta Barat. Hasil ini sedikit berbeda dengan penelitian yang dilakukan oleh Bandura (dalam Gunawan, 
2013) yang mengatakan bahwa Mastery Experience merupakan sumber efikasi diri yang paling mempengaruhi efikasi diri seseorang. Penelitian lainnya juga dilakukan oleh Nasta (2007) yang menyatakan bahwa Mastery Experience berkorelasi tinggi dengan efikasi diri karier seseorang. Berbeda dengan penelitian Gunawan (2013) yang menyatakan bahwa sumber efikasi diri yang paling mempengaruhi adaptabilitas karier adalah Verbal Persuasion. Berdasarkan beberapa penelitian didapatkan hasil yang berbeda, hal tersebut disebabkan oleh beberapa faktor. Pajares dan Usher (2008) mengatakan perbedaan hasil dapat terjadi karena adanya perbedaan karakteristik subjek, baik dari usia, jenis kelamin, etnis, dan level akademis.

Ketiga sekolah yang digunakan menjadi sampel dalam penelitian ini tergolong dalam kategori tinggi. Uji beda yang dilakukan dengan menggunakan One way Anova menunjukkan hasil bahwa terdapat perbedaan yang signifikan antara ketiga sekolah tersebut. Sekolah yang digunakan dalam penelitian ini terdiri dari jenis sekolah yang berbeda. SMA 2 termasuk dalam sekolah negeri di Jakarta Barat, SMA IPEKA Tomang merupakan sekolah swasta dengan basis agama Kristen, sedangkan SMA Al-Huda adalah sekolah swasta yang berbasis agama Islam. Ketiga sekolah ini memiliki guru BK (bimbingan konseling) yang memantau perkembangan akademis mereka. Menurut Santrock (dalam Bachrie, 2009), sekolah merupakan salah satu sarana potensial dalam membentuk kepribadian individu, identitas diri, keyakinan akan kemampuan diri, hubungan antarpribadi, batasan norma antara yang baik dan yang buruk, serta konsep akan sistem sosial selain keluarga. Berdasarkan hal-hal tersebut maka pengalaman yang diperoleh di sekolah sangat penting untuk pembentukan diri mereka secara intelektual, sosial dan emosional. Bachrie (2009) dalam penelitiannya mengatakan bahwa siswa SMA yang bersekolah di sekolah negeri dan swasta memiliki perbedaan dalam karakter dirinya, berdasarkan proses identifikasi mereka terhadap lingkungannya.

Berdasarkan nilai rata-rata setiap sekolah, diketahui nilai rata-rata SMA 2 paling tinggi dibandingkan dua sekolah lainnya. SMA 2 merupakan sekolah negeri ternama di Jakarta Barat, selain itu fasilitas yang disediakan di sekolah ini tidak jauh berbeda dengan sekolah swasta. SMA 2 yang berstatus sekolah negeri ini termasuk dalam jajaran sekolah favorit dan memiliki prestasi yang baik (Carapedia, 2011). Meskipun sekolah ini bukan merupakan sekolah terfavorit pertama, namun sekolah ini menjadi salah satu sekolah negeri pilihan di Jakarta Barat. Keberadaan SMA 2 yang menjadi salah satu sekolah negeri favorit Jakarta membuat siswa-siswa yang berada di dalamnya memiliki sumbersumber efikasi diri yang lebih tinggi dibanding siswa di sekolah lainnya. Sekolah dengan kategori tertinggi kedua adalah SMA IPEKA Tomang, yang merupakan sekolah swasta yang memiliki akreditasi A. Menurut hasil survey dikatakan bahwa SMA IPEKA Tomang termasuk dalam 10 SMA Swasta favorit di Jakarta (Carapedia, 2011). Hal tersebut juga mempengaruhi tingginya sumbersumber efikasi diri karier dari siswa-siswa yang ada di sekolah ini. Sekolah ketiga adalah SMA Al-Huda, meskipun sekolah ini bukan merupakan sekolah favorit, namun sekolah ini memiliki sumbersumber efikasi diri karier yang tinggi juga. SMA Al-Huda sudah terakreditasi A dengan nilai akreditasi sebesar 92.51 (BAN-SM, 2014).

Jenis kelamin perempuan dan lakilaki dalam penelitian ini memiliki sumbersumber efikasi diri karier yang tergolong tinggi. Meskipun keduanya tergolong tinggi namun tetap terdapat perbedaan sumber-sumber efikasi diri karier yang signifikan antara keduanya. Hasil ini sejalan dengan hasil penelitian Zimmerman (Bandura, 1997) yang mengatakan bahwa terdapat perbedaan 
pada perkembangan kemampuan dan kompetensi laki-laki dan perempuan. Pada bidang pekerjaan tertentu laki-laki bisa memiliki efikasi diri yang lebih tinggi dibanding dengan perempuan, begitu juga sebaliknya perempuan unggul dalam beberapa pekerjaan dibandingkan dengan laki-laki. Peneliti memperoleh hasil sumber-sumber efikasi diri karier pada perempuan lebih tinggi dibandingkan sumber-sumber efikasi diri karier pada laki-laki. Hal tersebut dapat dilihat dari nilai rata-rata jenis kelamin perempuan lebih tinggi daripada nilai rata-rata jenis kelamin laki-laki.Hal ini dinyatakan juga oleh Bandura (1997) dalam penelitiannya bahwa perempuan memiliki efikasi diri yang lebih tinggi dalam mengelola peranannya. Namun penelitian Huang (2011) mengatakan bahwa dalam hal sosial, matematika, dan ilmu pengetahuan, laki-laki memiliki efikasi diri yang lebih tinggi daripada perempuan.

Penelitian ini menyatakan tidak ada perbedaan yang signifikan antara sumbersumber efikasi diri karier pada usia 17 tahun dan 18 tahun. Keduanya tergolong dalam kategori tinggi. Hasil penelitian ini berbeda dengan pernyataan Bandura (1997) yang mengatakan bahwa seiring bertambahnya usia seseorang maka semakin banyak pengalaman yang didapatkan, sehingga menyebabkan efikasi diri seseorang semakin meningkat juga. Bandura (1997) mengatakan bahwa semakin banyak pengalaman dan masalah yang mampu diatasi, efikasi diri seseorang akan semakin berkembang. Penelitian lain menemukan bahwa pekerja yang berusia muda lebih mudah berganti-gani pekerjaan dibandingkan pekerja yang berusia lebih tua (Acker, 1999). Sumber-sumber efikasi diri karier remaja usia 17-18 tahun pada penelitian ini tergolong sedang. Namun menurut Ginzberg (Winkel, 1991) pada usia 17-18 tahun, seharusnya sudah mampu memikirkan atau merencanakan karier mereka berdasarkan minat, kemampuan dan nilai-nilai yang ingin diperjuangkan. Remaja akan sulit untuk merencanakan suatu tujuan karier jika mereka tidak yakin akan kemampuan dirinya, maka dari itu penting untuk memiliki efikasi diri yang tinggi pada usia ini.

Berdasarkan kelas jurusan IPA dan IPS diketahui bahwa keduanya tidak memiliki perbedaan secara signifikan. Selain itu keduanya memiliki kontribusi yang sama dalam sumber-sumber efikasi diri karier, keduanya tergolong dalam kategori tinggi. Hasil ini tidak sejalan dengan fenomena yang terjadi di masyarakat luas. Banyak siswa-siswi, orang tua, bahkan guru yang menilai bahwa siswa yang berada di kelas jurusan IPA lebih pintar daripada siswa di kelas jurusan IPS. Namun, Friedman (1998) mengatakan bahwa hasil akademis tidak menjamin seseorang akan mampu untuk menyelesaikan masalah atau berhasil mengerjakan tugas-tugas tertentu, penilaian terhadap efikasi diri masingmasing individu yang menentukan kemampuan tersebut. Menurut Lent, Brown, dan Larkin (1984) siswa yang memiliki keyakinan tinggi terhadap kemampuannya akan mencapai nilai yang lebih tinggi dan bertahan lebih lama di jurusan yang mereka pilih. Mone, Baker, dan Jeffries (1995) melalui penelitiannya juga mengatakan bahwa efikasi diri memiliki pengaruh yang besar terhadap kinerja akademik seseorang. Schunk (1984) mengatakan, siswa dengan pencapaian kinerja sebelumnya yang serupa dapat memiliki keterampilan kognitif yang berbeda dalam kinerja berikutnya. Hal tersebut sebagai akibat dari perbedaan persepsi efikasi diri mereka, karena persepsi efikasi diri adalah gabungan antara pencapaian sebelumnya dan kinerja akademik. Melalui penelitianpenelitian tersebut, peneliti dapat menyimpulkan bahwa tidak ada perbedaan antara kelas jurusan IPA dan IPS karena yang menetukan keberhasilan mereka dalam menyelesaikan tugas dan pekerjaan adalah sejauhmana mereka yakin akan kemampuan yang mereka miliki. 


\section{SIMPULAN}

Gambaran sumber-sumber efikasi diri karier remaja usia 17-18 tahun di Jakarta Barat tergolong tinggi. Keempat dimensi sumber-sumber efikasi diri karier tergolong dalam kategori tinggi, yang artinya keempat dimensi tersebut memiliki kontribusi yang sama tingginya terhadap efikasi diri karier remaja usia 17-18 tahun di Jakarta Barat. Hasil penelitian ini berbeda dengan penelitian-penelitian yang ada sebelumnya, hal tersebut dapat terjadi karena banyak faktor yang mempengaruhinya. Faktor-faktor tersebut dapat berupa usia, jenis kelamin, level akademis, dan etnis. Jadi, disimpulkan bahwa sumber-sumber efikasi diri karier yang tinggi dapat membentuk efikasi diri karier yang tinggi juga, dalam penelitian ini efikasi diri karier yang dimiliki oleh remaja usia 17-18 tahun di Jakarta Barat.

Gambaran demografis pada penelitian ini didapatkan dari sekolah SMA, usia, jenis kelamin, dan kelas jurusan. Perbedaan sumber-sumber efikasi diri karier antara ketiga sekolah SMA tersebut signifikan, yang artinya ketiga sekolah tersebut memiliki perbedaan dalam sumber-sumber efikasi diri karier. Sumbersumber efikasi diri karier ketiga sekolah tersebut tergolong dalam kategori tinggi, dengan SMA 2 memiliki nilai rata-rata tertinggi dibandingkan kedua sekolah lainnya. Berdasarkan jenis kelamin, terdapat perbedaan yang signifikan antara keduanya. Dalam penelitian ini menunjukkan bahwa sumber-sumber efikasi diri karier memiliki nilai rata-rata yang lebih tinggi dibandingkan nilai ratarata pada jenis kelamin laki-laki. Usia yang digunakan dalam penelitian ini terdiri dari usia 17 dan 18 tahun. Hasil penelitian menunjukkan tidak ada perbedaan yang signifikan dalam hal usia. Sumber-sumber efikasi diri karier kedua usia tersebut tergolong tinggi. Namun berdasarkan penelitian ahli sebelumnya, dikatakan bahwa seharusnya semakin tinggi usia seseorang maka semakin tinggi pula efikasi dirinya. Jika dilihat dari kelas jurusan IPA dan IPS maka dapat dilihat bahwa tidak ada perbedaan antara keduanya. Baik kelas jurusan IPA maupun IPS, keduanya dapat meraih keberhasilan yang sama, keberhasilan tersebut ditentukan oleh sejauh mana mereka memiliki keyakinan terhadap diri sendiri.

\section{SARAN}

Saran untuk penelitian selanjutnya adalah dapat melakukan penelitian lanjutan dengan melihat pengaruh sumber-sumber efikasi diri dengan variabel karier lainnya, seperti pengambilan keputusan karier, keraguan karier dan lainnya. Penelitian selanjutnya juga dapat diperdalam dengan memperluas subjek penelitian dan melihat faktor-faktor demografis lain yang memengaruhi sumber-sumber efikasi diri karier, seperti usia yang lebih variartif, kondisi sosial ekonomi, etnis dan level akademis.

\section{DAFTAR PUSTAKA}

Acker, G. M. (1999). The impact of clients' mental illness on social workers' job satisfaction and burnout. Health and Social Work, 24(2), 112-119.

Anderson, S. L., \& Betz, N. E. (2001). Sources of social self-efficacy expectations: their measurement and relation to career development. Journal of vocational behavior, 58, 98-117.

Ariani, Y. (2011). Hubungan antara motivasi dengan efikasi diri pasien dm tipe 2 dalam konteks asuhan keperawatan di RSUP. H. Adam Malik Medan. Diunduh dari

http://lontar.ui.ac.id/file?file=digital/2028 2755-T\%20Yesi\%20Ariani.pdf.

Azwar, S. (2012). Reliabilitas dan validitas (edisi ke-4). Yogyakarta: Pustaka Pelajar.

Azwar, S. (2013). Metode penelitian. Yogyakarta: Pustaka Pelajar.

Bacanli, F. (2006). Career search self-efficacy expectation scale: Validity and reliability studies. Turkey: Gazi University.

Bachrie, N. S. (2009). Hubungan jenis sekolah dan identifikasi nilai moral individualisme terhadap kesadaran sosial siswa SMA di Jakarta. Jakarta: Universitas Indonesia. 
Bandura, A. (1986). Social foundations of thought and action: A social cognitive theory. Englewood Cliffs, NJ: PrenticeHall, Inc.

Bandura, A. (1997). Self-efficacy: The exercise of self-control. New York: W.H. Freeman and Company.

Betz, N. E. (1992). Counseling uses of career self-efficacy theory. Career Development Quarterly, 41, 22-27.

Betz, N. E., \& Hacket, G. (1986). Applications of self-efficacy Theory to understanding Career choice behavior. Journal of Social and Clinical Psychology, 4(4), 279-289

Betz, N. E., Klein, K.l., \& Taylor, K. M. (2012). Evaluation of short from of the career decision-making self-efficacy scale. Journal of Career Assessment, 4, 45-57.

Doi: $10.1177 / 106907279600400103$

Bozgeyikli, H., Susran, Erkan, E., Habib, H. (2009). Career decision making selfefficacy, career maturity and socioeconomic status with Turkish youth. Georgian electronic scientific journal: Education science and psychology, 1(14), 15-24.

Brown, S.D., Lent, R.W. (2014). Career Development and Counseling: Putting Theory and Research to Work. John Wiley \& Sons.

Creed, P., Patton, W., \& Prideaux, L. (2006). Causal relationship between career indecision and career decision-making self-efficacy. Journal of Career Development, 33(1), 47-65.

Dariyo, A. (2004). Psikologi perkembangan remaja. Jakarta: Ghalia Indonesia.

Ferguson, P. A. (2007). A relationship between career decision and motivation to persist. Florida: University of Central Florida.

Friedman, H. S. (1998). Encyclopedia of mental health. San Diego: Academic Press.

Gati, I., \& Saka, N. (2001). High school students' career-related decision making difficulties. Journal of counseling and development, 79(3), 331-340.

Ginzberg, E., Ginsburg, S. W., Axelrad, S., \& Herma, J. L. (1951). Occupational choice, an approach to a general theory. New York: Columbia University Press.

Gunawan, W. (2013). Pengaruh sumbersumber efikasi diri dan efikasi diri pengambilan keputusan karier terhadap adaptabilitas karier remaja (Tesis tidak dipublikasi). Jakarta: Universitas Indonesia.

Isaacson, L. E. (1985). The basics of career counseling. Boston: Allyn \& Bacon, Inc.

Lazarus, R. S., Cohen, J. B., Folkman, S., Kanner, A., \& Schaefer, C. (1980). Psychological stress and adaptation: Some unresolved issues. Stress Research, 1, 90-117.

Lent, R. W., Brown, S. D., \& Larkin, K. C. (1984). Relation of self-efficacy expectations to academic achievement and persistence. Journal of Counseling Psychology, 31, 356-362.

Lestari, W. T. (2012). Relationship between self-efficacy with career maturity at the end college students. Yogyakarta: Universitas Ahmad Dahlan. Retrieved on Sep 9, 2015 from : https://goo.gl/g04T1b

Lin, Y. (2008). Job search self-efficacy of east asian international graduate students. Journal of Career Development, 43, 178216. Retrieved on Sep 9, 2015 from https://goo.gl/zEqoxb

Mone, M. A., Baker, D. D., \& Jeffries, F. (1995). Predictive validity and time dependency of self-efficacy, self-esteem, personal goals, and academic performance. Educational and Psychological Measurement, 55, 716-722.

Muretta, R. J. (2004). Exploring the four source of self-efficacy. Diunduh dari http://www.uky.edu/ eushe2/Pajares/Eff Muretta.pdf.

Nasta, K.A. (2007). Influence of career selfefficacy beliefs on career exploration behaviors. Diunduh dari http://dspace.sunyconnect.suny.edu/bitstr eam/handle/1951/42318/KristenNastaMas tersThesis.pdf?sequence $=1$.

Niles, S. G., \& Sowa, C. J. (1992). Mapping the nomological network of career selfefficacy. Career development quarterly, 41, 13-22.

Pajares, F., \& Usher, E. L. (2008). Sources of Self-Efficacy in School: Critical Review of the Literature and Future Directions. Review of Educational Research, 78(4), 751-796.

Papalia, D. E., Olds, A. W., \& Feldman, R. D. (2004). Human development (9th ed.). New York: McGraw-Hill.

Rachmawati, T. E. (2012). Hubungan antara self efficacy dengan kematangan karier 
pada mahasiswa tingkat awal dan tingkat akhir di Universitas Surabaya. Jurnal Ilmiah Mahasiswa Universitas Surabaya, 1(1). Retrieved on Nov 2, 2015 from https://goo.gl/YgszWR

Santrock, J. W. (2005). Adolesence (10th ed.). New York: McGraw-Hill.

Sawitri, D. R. (2009). Pengaruh status identitas dan efikasi diri keputusan karier terhadap keraguan mengambil keputusan karier pada mahasiswa tahun pertama di universitas Diponegoro. Jurnal Psikologi Undip, 5(2).

Schunk, D. H. (1984). Self-efficacy perspective on achievement behavior. Educational Psychologist, 19, 48-58.

Seligman, L. (1994). Development career counseling and assessment (2nd ed.). California: Sage Publication.

Sharf, R. S. (2006). Applying career development theory to counseling (4th ed.). USA: Thomson Brooks/Cole.

Sukadji, S. (2000). Psikologi pendidikan dan psikologi sekolah. Depok: LPSP3 Universitas Indonesia.
Wijaya, F. (2009). Hubungan antara kematangan karier dengan motivasi belajar pada siswa kelas $x$ man cibinong. Diunduh dari http://www.gunadarma.ac.id/library/articl es/graduate/psychology/2009/Artikel_105 03080.pdf.

Winkel, W.S. (1991). Bimbingan dan konseling di institusi pendidikan. Jakarta: PT Gramedia Widiasarana Indonesia.

Wulandari, S. (n.d.). Pengaruh efikasi diri terhadap minat berwirausaha pada siswa kelas xii di smk negeri 1 surabaya. Diunduh dari http://id.scribd.com/doc/126858679/Untitl ed\#download

Yulia, Y. V. (2010). Efektivitas pelatiahan amy (achievement motivation training) dengan pendekatan spiritual terhadap peningkatan efikasi diri mahasiswa tingkat awal dalam penyesuaian akademik. Diunduh dari http://digilib.uinsuka.ac.id/4311/1/bab\%2 0i,v ,\%20daftar\%20pustaka.pdf. 